\title{
The remarkable similarity between the acid-base properties of ISFETs and proteins and the consequences for the design of ISFET biosensors
}

\author{
P. Bergveld, R.E.G. van Hal \& J.C.T. Eijkel \\ MESA Research Institute, University of Twente, Box 217, 7500 AE Enschede, The Netherlands \\ Tel: [31] 53899111 Fax: [31] 53354003
}

(Received 1 June 1994; revised 19 October 1994; accepted 11 November 1994)

\begin{abstract}
Studying the acid-base properties of protein molecules led us to reconsider the operational mechanism of ISFETs. Based on the site-dissociation model, applied to the amphoteric metal oxide gate materials used in ISFETs, the sensitivity of ISFETs is described in terms of the intrinsic buffer capacity of the oxide surface, $\boldsymbol{\beta}_{\mathrm{s}}$, and the electrical surface capacitance, $\mathrm{C}_{\mathrm{s}}$. The ISFET sensitivity towards changes in the bulk $\mathrm{pH}$ is fully described by the ratio $\beta_{\mathrm{s}} /$ $\mathrm{C}_{\mathrm{s}}$. Practical measurements support this theoretical approach.

The new approach to the description of the acid-base properties of ISFETs is analogous to the classical description of the acid-base properties of protein molecules. The acid-base titration of proteins is also determined by the ratio between the intrinsic buffer capacity and the electrical double layer capacitance.

In addition to the amazing conclusion that ISFET surfaces and protein molecules behave in a similar way with respect to their acid-base properties, further conclusions are drawn with respect to the possibility of protein characterization by means of dynamic measurements with protein covered ISFETs. Design rules are given for this type of biosensors, based on the theoretical understanding of the acid-base behaviour of both sensor parts.
\end{abstract}

Keywords: ISFET, protein, biosensor

\section{INTRODUCTION}

Since the first papers and patents on Ion-Sensitive Field-Effect Transistors (ISFETs) (Bergveld, 1972; US Patent, 1977) there has been much interest in the development of biosensors in which the transducing element is an ISFET and the recognition system is a layer of protein deposited onto the gate of the ISFET. Enzyme sensors and immunosensors, in this case Enzyme FETs (ENFETs) and Immuno FETs (IMFETs), were initially expected to come into existence rapidly with the advantages of simple construction and use of limited amounts of mostly expensive substances.

The development of ENFETs appears indeed to be simple for those substrates that create a large enough local change in $\mathrm{pH}$, in a membrane containing the appropriate immobilized enzymes, measured by the integrated ISFET (Kuriyama $e t$ $a l ., 1985)$. The main advantage over other systems is the possibility of the additional integration of 
a coulometric $\mathrm{pH}$ actuator, which can, when connected in a feedback loop, keep the membrane $\mathrm{pH}$ at a constant predetermined value. Such a pH-static enzyme sensor is able to measure substrate concentrations linearly, over an extended range, independent of the buffer capacity of the sample solution (van der Schoot and Bergveld, 1988; van der Schoot and Bergveld, 1990).

The development of IMFETs appears to be more difficult than originally expected because initial research efforts were based on an incorrect assumption. It was expected that the inherent charge of antibody molecules attached to the gate of an ISFET would create an external electric field which would be sensed by the FET structure. A reaction with antigen molecules would modulate this field and thus reactions would be measured by the ISFET (Schenck, 1978). Only recently papers appeared in which it was explained and proven that such an operational mechanism cannot exist due to the fact that counter ions would shield the charged protein molecules, and this would result in an absence of an external electric field beyond a distance determined by the Debye length of the sample solution (Schasfoort et al., 1990a). Binding proteins to the surface of an ISFET within this distance is not a realistic possibility.

From the theory of acid-base properties of proteins it is known, however, that specific groups bound to the peptide side and end chains are able to be protonated or deprotonated depending on the $\mathrm{pH}$ and ionic strength of the surrounding electrolyte. Modulation of the ionic strength will modulate the protonation and thus modulate the local $\mathrm{pH}$ around the protein molecules. In this way a new possibility of measurement is introduced: an induced local $\mathrm{pH}$ change in a protein layer deposited on an ISFET gate can be measured by the ISFET. In this case advantage can be taken of the small planar performance of the ISFET and the fast response to (local) $\mathrm{pH}$ changes.

Investigations into the protonation and deprotonation of amino, carboxyl and other titratable groups of protein molecules in terms of the corresponding buffer capacity and the electrical double layer potential and capacitance, led to the opinion that it should be possible to describe the protonation and deprotanation of the hydroxyl groups existing at the gate oxide surface of an ISFET with the same parameters. Indeed, this appears to be possible and the new theoretical approach is given in the next section. The alternative description shows that the operational mechanism of ISFETs cannot only be described more simple than in the original theory (Bousse et al., 1983), but can also be more easily understood.

After realizing the significance of buffer capacity and electrical double layer capacitance of an amphoteric surface, the same approach is used to describe the acid-base behaviour of protein molecules in the following section.

After a description of the fundamental acidbase behaviour of ISFET surfaces and protein molecules, the combination of both will be considered, as found in many affinity based ISFET biosensors. Some examples of the possibilities of the principle will be given and criteria for an optimal design of ISFET biosensors will be discussed.

\section{THE BUFFER CAPACITY OF AN AMPHOTERIC SURFACE}

The actual ISFET response mechanism is based on the acid-base behaviour of the gate insulator/ electrolyte interface. The usual gate insulators are inorganic metal oxides, which have amphoteric surface sites. This means that the surface hydroxyl groups may act as proton donors or acceptors, depending on the electrolyte $\mathrm{pH}$. The corresponding reactions are:

$$
\begin{aligned}
& \mathrm{A}-\mathrm{OH} \stackrel{\kappa_{\mathrm{a}}}{\Leftrightarrow} \mathrm{A}-\mathrm{O}^{-}+\mathrm{H}_{\mathrm{s}}^{+} \\
& \mathrm{A}-\mathrm{OH}+\mathrm{H}_{\mathrm{s}}^{+} \stackrel{\kappa_{\mathrm{b}}}{\Leftrightarrow} \mathrm{A}-\mathrm{OH}_{2}^{+},
\end{aligned}
$$

with the dissociation constants:

$$
\mathrm{K}_{\mathrm{a}}=\frac{\left[\mathrm{A}-\mathrm{O}^{-}\right]\left[\mathrm{H}_{\mathrm{s}}^{+}\right]}{[\mathrm{A}-\mathrm{OH}]}
$$

and

$$
\mathrm{K}_{\mathrm{b}}=\frac{\left[\mathrm{A}-\mathrm{OH}_{2}^{+}\right]}{[\mathrm{A}-\mathrm{OH}]\left[\mathrm{H}_{\mathrm{s}}^{+}\right]}
$$

Here $[\mathrm{A}-\mathrm{OH}]$ is the number of neutral sites per $\mathrm{cm}^{2}$, and $\left[\mathrm{A}-\mathrm{O}^{-}\right]$and $\left[\mathrm{A}-\mathrm{OH}_{2}^{+}\right]$the number of negative and positive surface groups per $\mathrm{cm}^{2}$, randomly divided over the surface, the values of which are determined by the respective equilibrium constants and the $\mathrm{pH}$ of the bulk solution, $\mathrm{pH}_{\mathrm{b}} \cdot\left[\mathrm{H}_{\mathrm{s}}^{+}\right]$represents the number of protonated water molecules, $\left[\mathrm{H}_{3} \mathrm{O}^{+}\right]$, per $\mathrm{cm}^{3}$ directly adjac- 
ent to the oxide surface, the significance of which becomes clear by combining equations 3 and 4 :

$$
\left[\mathrm{H}_{\mathrm{s}}^{+}\right]^{2}=\frac{\mathrm{K}_{\mathrm{a}}}{\mathrm{K}_{\mathrm{b}}} \frac{\left[\mathrm{A}-\mathrm{OH}_{2}^{+}\right]}{\left[\mathrm{A}-\mathrm{O}^{-}\right]},
$$

which shows that for a neutral surface $\left.\left[\mathrm{A}-\mathrm{OH}_{2}^{+}\right]=\left[\mathrm{A}-\mathrm{O}^{-}\right]\right)$:

$$
\left[\mathrm{H}_{\mathrm{s}}^{+}\right]=\sqrt{\frac{\mathrm{K}_{\mathrm{a}}}{\mathrm{K}_{\mathrm{b}}}}
$$

or

$$
\mathrm{pH}_{\mathrm{s}}=-\log \left[\mathrm{H}_{\mathrm{s}}^{+}\right]=-\log \sqrt{\frac{\mathrm{K}_{\mathrm{a}}}{\mathrm{K}_{\mathrm{b}}}} .
$$

This neutral equilibrium case is established for a value where $\mathrm{pH}_{\mathrm{b}}=\mathrm{pH}_{\mathrm{s}}$, which is generally known as the $\mathrm{pH}$ at the point of zero charge: $\mathrm{pH}_{\mathrm{pzc}}$.

Because each inorganic oxide is characterized by the values of $\mathrm{K}_{\mathrm{a}}$ and $\mathrm{K}_{\mathrm{b}}$, the value of $\mathrm{pH}_{\mathrm{pzc}}$ is also characteristic for a certain type of oxide. An interesting question is: what happens to the value of $\mathrm{pH}_{\mathrm{s}}$ when the surface is in contact with an electrolyte having a value of $\mathrm{pH}_{\mathrm{b}} \neq \mathrm{pH}_{\mathrm{pzc}}$ ? Or in other words: what happens to the value of $\mathrm{pH}_{\mathrm{s}}$ when the surface is titrated by protons or hydroxyl ions from the bulk electrolyte? This effect can be expressed in terms of the intrinsic buffer capacity of the surface, $\beta_{\mathrm{s}}$, which is by definition the ratio between a small amount of strong base $\mathrm{d}[\mathrm{B}]$ (or acid) and the resulting change in $\mathrm{pH}$, here $\mathrm{dpH}_{\mathrm{s}}$ :

$$
\beta_{\mathrm{s}}=\frac{\mathrm{d}[\mathrm{B}]}{\mathrm{dpH}} .
$$

In this particular case

$$
[\mathrm{B}]=\left[\mathrm{A}-\mathrm{O}^{-}\right]-\left[\mathrm{A}-\mathrm{OH}_{2}^{+}\right]=-\frac{\sigma_{\mathrm{s}}}{\mathrm{q}},
$$

where $\sigma_{\mathrm{s}}$ is the net surface charge of the titrated groups per $\mathrm{cm}^{2}$ and $\mathrm{q}=1.6 \mathrm{E}-19 \mathrm{C}$.

With the total number of charged and neutral surface groups

$$
\mathrm{N}_{\mathrm{s}}=\left[\mathrm{A}-\mathrm{O}^{-}\right]+\left[\mathrm{A}-\mathrm{OH}_{2}^{+}\right]+[\mathrm{A}-\mathrm{OH}]
$$

it can be calculated from equations 3,4 and 10 that:

$$
\left[\mathrm{A}-\mathrm{O}^{-}\right]=\mathrm{N}_{\mathrm{s}} \frac{\mathrm{K}_{\mathrm{a}}}{\mathrm{K}_{\mathrm{a}}+\left[\mathrm{H}_{\mathrm{s}}^{+}\right]+\mathrm{K}_{\mathrm{b}}\left[\mathrm{H}_{\mathrm{s}}^{+}\right]^{2}}
$$

and

$$
\left[\mathrm{A}-\mathrm{OH}_{2}^{+}\right]=\mathrm{N}_{\mathrm{s}} \frac{\mathrm{K}_{\mathrm{b}}\left[\mathrm{H}_{\mathrm{s}}^{+}\right]^{2}}{\mathrm{~K}_{\mathrm{a}}+\left[\mathrm{H}_{\mathrm{s}}^{+}\right]+\mathrm{K}_{\mathrm{b}}\left[\mathrm{H}_{\mathrm{s}}^{+}\right]^{2}} .
$$

Thus

$$
\begin{aligned}
\beta_{\mathrm{s}} & =\frac{\mathrm{d}[\mathrm{B}]}{\mathrm{dpH}}=\frac{\mathrm{d}[\mathrm{B}]}{\mathrm{d}\left[\mathrm{H}_{\mathrm{s}}^{+}\right]} \cdot \frac{\mathrm{d}\left[\mathrm{H}_{\mathrm{s}}^{+}\right]}{\mathrm{dpH}} \\
& =\mathrm{N}_{\mathrm{s}} \frac{\mathrm{K}_{\mathrm{a}}+4 \mathrm{~K}_{\mathrm{a}} \mathrm{K}_{\mathrm{b}}\left[\mathrm{H}_{\mathrm{s}}^{+}\right]+\mathrm{K}_{\mathrm{b}}\left[\mathrm{H}_{\mathrm{s}}^{+}\right]^{2}}{\left(\mathrm{~K}_{\mathrm{a}}+\left[\mathrm{H}_{\mathrm{s}}^{+}\right]+\mathrm{K}_{\mathrm{b}}\left[\mathrm{H}_{\mathrm{s}}^{+}\right]^{2}\right)^{2}} \cdot 2.3\left[\mathrm{H}_{\mathrm{s}}^{+}\right]
\end{aligned}
$$

Equation 13 shows that the buffer capacity of an amphoteric surface is larger with a larger value of $\mathrm{N}_{\mathrm{s}}$ as well as with a larger value of $\mathrm{K}_{\mathrm{a}} \mathrm{K}_{\mathrm{b}}$, which is equivalent to a small value of $\Delta \mathrm{pK}=$ $\mathrm{pK}_{\mathrm{a}}+\mathrm{pK}_{\mathrm{b}}$.

Due to the intrinsic buffer capacity of the surface, the value of $\mathrm{pH}_{\mathrm{s}}$ does not track with the value of $\mathrm{pH}_{\mathrm{b}}$ during the titration, and this causes a surface potential, $\psi_{\mathrm{s}}$, according to the Boltzmann distribution:

$$
\left[\mathrm{H}_{\mathrm{s}}^{+}\right]=\left[\mathrm{H}_{\mathrm{b}}^{+}\right] \exp \left(-\mathrm{q} \psi_{\mathrm{s}} / \mathrm{kT}\right)
$$

or

$$
\psi_{\mathrm{s}}=2.3 \frac{\mathrm{kT}}{\mathrm{q}}\left(\mathrm{pH}_{\mathrm{s}}-\mathrm{pH}_{\mathrm{b}}\right) .
$$

The surface potential, $\psi_{\mathrm{s}}$, charges the electrical surface capacitance, $\mathrm{C}_{\mathrm{s}}$, consisting of the Stern layer capacitance $\mathrm{C}_{\text {stern }}$ in series with the diffuse layer capacitance $C_{\mathrm{dl}}$, giving:

$$
\mathrm{C}_{\mathrm{s}}^{-1}=\mathrm{C}_{\mathrm{dl}}^{-1}+\mathrm{C}_{\text {stern }}^{-1} \text {. }
$$

The related charge in the double layer is $\sigma_{\mathrm{dl}}=$ $-\sigma_{\mathrm{s}}$; thus:

$$
\sigma_{\mathrm{s}}=-\psi_{\mathrm{s}} \mathrm{C}_{\mathrm{s}} .
$$

If we now consider what happens with $\mathrm{pH}_{\mathrm{s}}$ when the bulk $\mathrm{pH}$ changes, it can be concluded that a change in the surface potential $d \psi_{\mathrm{s}}$ results from the induced $\mathrm{dpH}_{\mathrm{s}}$, according to equations 8,9 and 17:

$$
\frac{\mathrm{d} \psi_{\mathrm{s}}}{\mathrm{dpH} H_{\mathrm{s}}}=\frac{\mathrm{d} \sigma_{\mathrm{s}}}{\mathrm{dpH} H_{\mathrm{s}}} \frac{\mathrm{d} \psi_{\mathrm{s}}}{\mathrm{d} \sigma_{\mathrm{s}}}=\frac{-\mathrm{q} \beta_{\mathrm{s}}}{\mathrm{C}_{\mathrm{s}}}
$$

under the condition that $\mathrm{Cs}$ is independent of $\psi_{\mathrm{s}}$, which is in most cases a reasonable assumption (Westall \& Hohl, 1980).

Equation 18 shows that for a small value of $\mathrm{dpH}_{\mathrm{s}}$ a large value of $\mathrm{d} \psi_{\mathrm{s}}$ will occur in cases of surfaces with a large intrinsic buffer capacity, $\beta_{\mathrm{s}}$, especially when combined with a small electrical surface capacitance, $\mathrm{C}_{\mathrm{s}}$. 


\section{THE PH SENSITIVITY OF AN ISFET}

Because an ISFET is essentially a device that measures exclusively the gate insulator/electrolyte interfacial potential, $\psi_{\mathrm{s}}$, as a function of the $\mathrm{pH}$ of the bulk electrolyte, $\mathrm{pH}_{\mathrm{b}}$, equation 15 must be differentiated in order to determine the $\mathrm{pH}$ sensitivity of an ISFET:

$$
\begin{aligned}
\frac{\mathrm{d} \psi_{\mathrm{s}}}{\mathrm{dpH} H_{\mathrm{b}}} & =2.3 \frac{\mathrm{kT}}{\mathrm{q}}\left(\frac{\mathrm{dpH} H_{\mathrm{s}}}{\mathrm{dpH} H_{\mathrm{b}}}-1\right) \\
& =2.3 \frac{\mathrm{kT}}{\mathrm{q}}\left(\frac{\mathrm{dpH}}{\mathrm{d} \psi_{\mathrm{s}}} \frac{\mathrm{d} \psi_{\mathrm{s}}}{\mathrm{dpH}}-1\right)
\end{aligned}
$$

Rewriting equation 19 gives:

$$
\frac{\mathrm{d} \psi_{\mathrm{s}}}{\mathrm{dpH} H_{\mathrm{b}}}=\frac{2.3 \frac{\mathrm{kT}}{\mathrm{q}}}{\frac{2.3 \mathrm{kT}}{\mathrm{q}} \cdot \frac{\mathrm{dpH} H_{\mathrm{s}}}{\mathrm{d} \psi_{\mathrm{s}}}-1} .
$$

Combining equations 18 and 20 results in:

$$
\frac{\mathrm{d} \psi_{\mathrm{s}}}{\mathrm{dpH} H_{\mathrm{b}}}=-2.3 \frac{\mathrm{kT}}{\mathrm{q}} \frac{1}{2.3 \frac{\mathrm{kT}}{\mathrm{q}^{2}} \frac{\mathrm{C}_{\mathrm{s}}}{\beta_{\mathrm{s}}}+1}=-2.3 \alpha \frac{\mathrm{kT}}{\mathrm{q}} \text {. }
$$

The $\mathrm{pH}$ sensitivity of an ISFET with an inorganic oxide as the gate material can thus be described with a rather simple sensitivity parameter, $\alpha$, which approaches unity for large values of $\beta_{\mathrm{s}} / \mathrm{C}_{\mathrm{s}}$. This means that surfaces with a large buffer capacity (large value of $\mathrm{N}_{s}$ and low value of $\Delta \mathrm{pK}$ ) and a low value of $\mathrm{C}_{\mathrm{s}}$ (low electrolyte concentration) exhibit at best a maximum response of $59.3 \mathrm{mV}$ at $25^{\circ} \mathrm{C}$.

In practice certain oxides, such as $\mathrm{Ta}_{2} \mathrm{O}_{5}$, have such a large value of the intrinsic buffer capacity $\beta_{\mathrm{s}}$, that variations in the value of $\mathrm{C}_{\mathrm{s}}$ have hardly any effect on the $\mathrm{pH}$ sensitivity. This explains why $\mathrm{Ta}_{2} \mathrm{O}_{5}$ ISFETs show a maximum response of $59.3 \mathrm{mV}$ at $25^{\circ} \mathrm{C}$, independent of the electrolyte concentration, and why $\mathrm{SiO}_{2}$ ISFETs show a low $\mathrm{pH}$ sensitivity, which is also strongly influenced by the electrolyte concentration. Both effects are illustrated with the experimental results in Fig. $1 \mathrm{a}$ and $1 \mathrm{~b}$.

\section{ACID-BASE PROPERTIES OF PROTEIN MOLECULES TREATED AS ISFET SURFACES}

In contrast to theoretical investigations of the ISFET operational mechanism, which date from

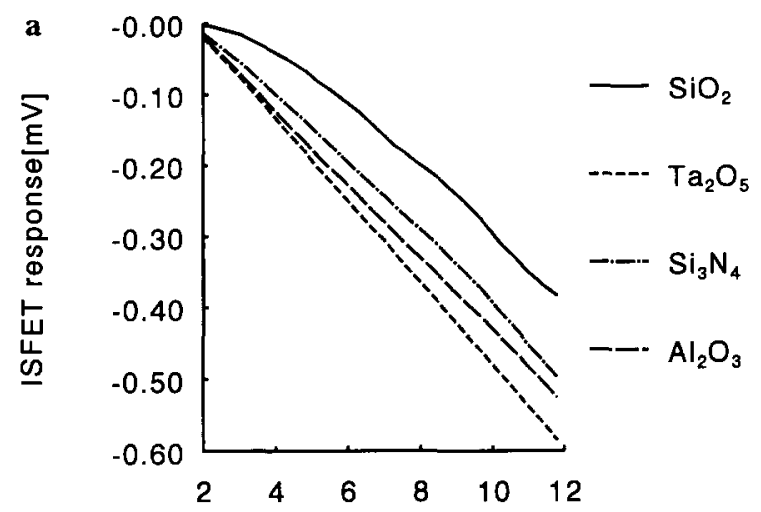

$\mathrm{pH}$

b

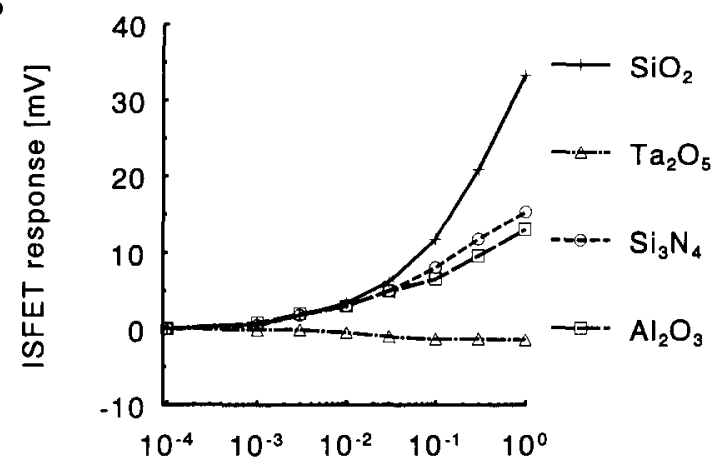

$[\mathrm{NaCl}]$

Fig. 1. (a) ISFET responses to electrolyte pH at constant $T B A C l$ concentration $(0.1 \mathrm{M})$.

(b) ISFET responses to $\mathrm{NaCl}$ electrolyte concentration at constant $\mathrm{pH}(=5 \cdot 8)$.

the 1970s, theoretical investigations of the acid-base behaviour of protein molecules date from the beginning of the century. Shortly after the fundamental description of the electrostatic properties of ions by Debye \& Hückel (1923), Linderstrøm-Lang (1924) used this approach to describe the electrostatic free energy of protein molecules. A protein molecule was modelled as consisting of an impenetrable sphere, occupied with discrete unit charges $\left(-\mathrm{NH}_{3}^{+},-\mathrm{COO}^{-}\right.$, etc.) and thus behaving as a kind of macro-ion. This early simple, but original approximation has long been used with considerable success. In order to explain the non-idealities observed in hydrogen titration curves of protein-containing aqueous solutions, many additional theoretical descriptions have been published since then, often as part of an independent scientific field of research: the physical chemistry of macromol- 
ecules. Many textbooks have been published and are still appearing with ever more detailed descriptions and modifications of the original simple model and related descriptions of protein molecules.

In the context of this paper, which aims to compare the acid-base properties of amphoteric surfaces, as described in the previous section, with those of protein molecules, application of the original simple model of a protein molecule is sufficient. The impenetrable sphere, occupied by titratable groups, can be compared with the impenetrable oxide with surface sites. The difference is that the inorganic oxides usually have only one type of surface group (hydroxyl), whilst a protein molecule has several types of "surface" groups, depending on the peptide side chains present. This means that for the acid-base description of a protein molecule the two equilibrium reactions, described by equations 1 and 2 for an amphoteric oxide, have to be replaced by many similar equations for the different protein groups, with as many equilibrium constants. Since titratable protein groups can accept or donate a proton, depending on the external $\mathrm{pH}$, protein molecules also exhibit a "point of zero charge" analogous to the oxide surfaces. However, in the case of protein molecules this point is known as the iso-electric point, $\mathrm{pH}_{\text {iep }}$.

From the titration curve of a protein solution, in principle the different $\mathrm{pK}$ values can be deduced, although this is often difficult to perform because of the small differences between different pK values. Nevertheless, the apparent buffer capacity of the protein solution (disregarding the buffer capacity of the solvent) as a function of the $\mathrm{pH}$ and the electrolyte concentration can be calculated, from:

$$
\beta_{\mathrm{app}}=\frac{\mathrm{d}[\mathrm{B}]}{\mathrm{dpH}},
$$

where $d[B]$ is equal to the change in the number of titrated groups per protein molecule resulting from a change of the bulk $\mathrm{pH}, \mathrm{dpH}_{\mathrm{b}}$.

In the previous section the intrinsic buffer capacity, $\beta \mathrm{s}$, of an amphoteric oxide surface was defined with respect to the $\mathrm{pH}$ of the adjacent layer of water: $\mathrm{pH}_{\mathrm{s}}\left(\beta_{\mathrm{s}}=\mathrm{d}[\mathrm{B}] / \mathrm{dpH}_{\mathrm{s}}\right)$. A similar intrinsic buffer capacity can also be defined for a protein surface (sphere model) using the Boltzmann distribution:

$$
\mathrm{pH}_{\mathrm{s}}=\mathrm{pH}_{\mathrm{b}}+\frac{\mathrm{q} \psi_{\mathrm{s}}}{2.3 \mathrm{kT}}
$$

where in this case $\mathrm{pHs}$ is the surface $\mathrm{pH}$ and $\psi \mathrm{s}$ is the surface potential of the protein molecule. Differentiating equation 23 and using equations 19 and 20 , which holds also for the case of protein molecule surfaces, gives:

$$
\frac{\mathrm{dpH}_{\mathrm{s}}}{\mathrm{dpH}_{\mathrm{b}}}=1+\frac{\mathrm{d}}{\mathrm{dpH_{ \textrm {b } }}}\left(\frac{\mathrm{q} \psi_{\mathrm{s}}}{2.3 \mathrm{kT}}\right)=1-\alpha
$$

where $\alpha$ is essentially the same parameter which was defined as the sensitivity parameter of ISFETs in equation 21:

$$
\alpha=\frac{1}{\frac{2.3 \mathrm{kT}}{\mathrm{q}^{2}} \frac{\mathrm{C}_{\mathrm{s}}}{\beta_{\mathrm{s}}}+1} .
$$

Note that now, beside the apparent buffer capacity of a protein solution $\beta_{\text {app }}$ (equation 22), in addition an intrinsic buffer capacity, $\beta_{\mathrm{s}}$, is defined as:

$$
\beta_{\mathrm{s}}=\frac{\mathrm{d}[\mathrm{B}]}{\mathrm{dpH}}=\frac{\mathrm{d}[\mathrm{B}]}{\mathrm{dpH}} \frac{\mathrm{dpH}}{\mathrm{b} \mathrm{pH}_{\mathrm{s}}}=\beta_{\mathrm{app}} \frac{1}{1-\alpha}
$$

The intrinsic buffer capacity of a protein molecule has the same significance as it does for an ISFET, but is not measurable with a conventional acid-base titration and therefore not defined by the classical protein chemistry. Only in the case where $\alpha=0$, which is the equivalence of $\psi_{\mathrm{s}}=0$, does the measurable $\beta_{\mathrm{app}}=\beta_{\mathrm{s}}$. This may be the case for protein molecules with a very low value of $\beta_{\mathrm{s}}$ combined with a high value of $\mathrm{C}_{\mathrm{s}}$, which is achieved at a large ionic strength.

Note that the surface capacitance, $\mathrm{C}_{\mathrm{s}}$, of a protein molecule is more difficult to determine than it is for a flat oxide surface, due to the spherical shape of the model protein molecule and the complex molecule conformation. However, in most practical cases protein molecules will show a certain surface potential $\psi_{\mathrm{s}}$ resulting in a value of $\beta_{\text {app }}$ which will always be smaller than the intrinsic buffer capacity, $\boldsymbol{\beta}_{\mathrm{s}}$.

For an ISFET surface only one type of surface group, the hydroxyl group, determines the buffer capacity over a wide range of bulk $\mathrm{pH}$ values. In contrast, for protein molecules different "surface" groups determine the buffer capacity for different bulk $\mathrm{pH}$ values and therefore the buffer capacity is an average value and strongly dependent on the actual pH. Furthermore, the ionic strength 
influences the value of $\beta_{\mathrm{s}}$, because $\psi_{\mathrm{s}}$ is a function of it.

Nevertheless the considerations mentioned above reveal a large similarity between the acidbase properties of the inorganic gate materials of ISFETs and those of protein molecules and it is interesting to investigate how these acid-base systems may influence each other when integrated in a biosensor construction.

\section{COMBINING THE ACID-BASE PROPERTIES OF PROTEIN MOLECULES AND ISFETS}

In ISFET based biosensors a layer of proteins is usually immobilized directly onto the gate of the ISFET or incorporated in a membrane matrix, which is attached to the ISFET surface. In both cases the distance between the protein molecules and the ISFET gate will be larger than the Debye length of the electrolyte as already mentioned in the introduction. It may also be assumed that the double layers around the protein molecules do not overlap. Via the intramolecular space of the protein molecules the ISFET measures in this case the $\mathrm{pH}$ value of the electrolyte $\left(\mathrm{pH}_{\mathrm{b}}\right)$. Upon titration of the proteins, by adding $\mathrm{d}[\mathrm{B}]$, the ISFET will measure the resulting quasistatically $\mathrm{dpHb}$ (equation 22 ) but will not measure the related $d \psi_{\mathrm{s}}$ and $\mathrm{dpH}_{\mathrm{s}}$ (equation 24) of the protein molecules. This means that any externally induced modulation of $\psi_{\mathrm{s}}$ or $\mathrm{pH}_{\mathrm{s}}$ will also not be measured by the ISFET. Thus it is not expected that a useful sensor could be developed in this way.

The conviction that the state of an electrochemical equilibrium of protein molecules in an electrolyte cannot be measured with an electrical potential sensor, nor with a $\mathrm{pH}$ sensor, evokes the idea that a disturbance of such an equilibrium, with the inherent resulting proton redistribution perceptible over distances larger than the Debye length, could lead to a solution to the measurement problem. As a source of such disturbance the ionic strength seems an obvious choice because it influences the surface capacitance, $\mathrm{C}_{\mathrm{s}}$, and thus $\psi_{\mathrm{s}}$, resulting in a rearrangement of the protonation of the protein molecules. Such a dynamic measurement, carried out in a flowthrough system is called a stimulus-response measurement as often applied for investigations of physiological systems.

\section{STIMULUS-RESPONSE MEASUREMENTS WITH PROTEIN COVERED ISFETS}

When an ISFET with a covalently bound layer of protein molecules or with a membrane matrix with immobilized protein molecules is placed in a flow-through system in which a carrier stream of an electrolyte with a constant $\mathrm{pH}$ is streaming, the ISFET will measure this $\mathrm{pH}$ and the protein molecules will be in a certain state of equilibrium, corresponding with this $\mathrm{pH}$. After injection of a stimulus electrolyte, having the same $\mathrm{pH}$, but with an increased concentration of the supporting electrolyte, the protein molecules as well as the ISFET surface will immediately react to this change in ion concentration, due to convection. Both systems are characterized by a specific value of $\alpha$ determined by $\beta_{\mathrm{s}} / \mathrm{C}_{\mathrm{s}}$ of which the value of $\mathrm{C}_{\mathrm{s}}$ is increased stepwise, due to the fact that the value of the double layer capacitance is proportional to the square root of the electrolyte concentration. (The maximum value is determined by the Stern layer capacitance $\left(20 \mu \mathrm{F} / \mathrm{cm}^{2}\right)$ in the case of an ISFET, and is unknown for protein molecules.)

As a response to the sudden increase in $\mathrm{C}_{\mathrm{s}}$, the surface charge of the protein molecules, $\sigma_{\mathrm{s}}$ cannot change instantaneously. Thus the surface potential, $\psi_{\mathrm{s}}$, will directly drop, obeying a simple equation (equation 17). The consequence is (equation 14) that with a constant value of $\mathrm{pH}_{\mathrm{b}}$, the value of $\mathrm{pH}_{\mathrm{s}}$ is forced to adapt. The necessary protons have to be delivered or consumed by the surface and the ability to do so is determined by the intrinsic buffer capacity. The larger the intrinsic buffer capacity, the smaller the eventual change in $\mathrm{pH}_{\mathrm{s}}$ will be. The actual response to a concentration stimulus is thus a temporary proton release or uptake, until a new equilibrium is established, depending on the initial value of $\mathrm{pH}_{\mathrm{b}}$.

The next example may elucidate the stimulus-response mechanism. Suppose an ISFET with an integrated reference electrode is covered with a membrane with immobilized proteins, having a moderate value of intrinsic buffer capacity. Assume a value of $\mathrm{pH}_{\mathrm{b}}=7$ and $\mathrm{pH}_{\mathrm{s}}$ $=4$ for the protein molecules, which means that the surface potential of the proteins is $\psi_{\mathrm{s}}=$ $3 \times-59 \mathrm{mV}$. Suppose further that a stimulus with an increased value of supporting electrolyte, say $\mathrm{KNO}_{3}$, increases the value of $\mathrm{C}_{\mathrm{s}}$ in such a way that $\mathrm{d} \psi_{\mathrm{s}}=1 \times 59 \mathrm{mV}$, resulting in a new 
value of $\psi_{\mathrm{s}}=2 \times-59 \mathrm{mV}$. This means that the starting value of $\mathrm{pH}_{\mathrm{s}}=4$ is too low and deprotonation of the relevant side chain groups will occur in order to change $\mathrm{pH}_{\mathrm{s}}$. The resulting $\mathrm{pH}$ change is determined by the intrinsic buffer capacity of the proteins. Since the diffusion of protons is limited in the membrane, the $\mathrm{pH}$ in the intramolecular space, $\mathrm{pH}_{\mathrm{m}}$, may temporarily decrease from 7 to a maximum value of 6 . In the final equilibrium state, when the accumulated protons in the membrane are diffused into the bulk solution, the following values may (as an example) be established: $\mathrm{pH}_{\mathrm{b}}=7 ; \mathrm{pH}_{\mathrm{s}}=4.5$ and $\psi_{\mathrm{s}}=2.5 \times-59 \mathrm{mV}$. The procedure is schematically illustrated in Fig. 2.

The example clearly shows that, although the equilibrium state for the protein molecules has been changed (i.e. different values for $\mathrm{pH}_{\mathrm{s}}, \sigma_{\mathrm{s}}$ and $\psi_{\mathrm{s}}$ ), after the experiment the ISFET measures the same value of the bulk $\mathrm{pH}$. During and shortly after the stimulus, however, the ISFET measures the changed $\mathrm{pH}$ value in the intramol-

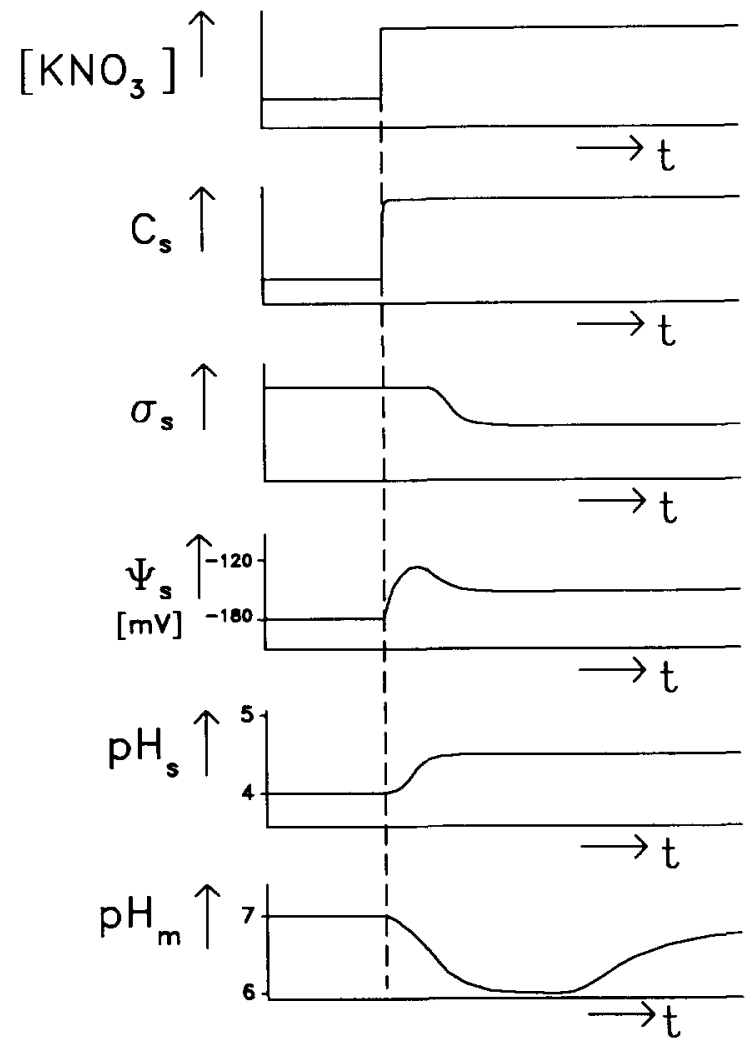

Fig. 2. Sequence of changes in $C_{s}, \sigma_{s}, \psi_{s}, p H_{s}$ and $\mathrm{pH}_{m}$ as a result of a stepwise change in the electrolyte concentration ([KNO $\left.\mathrm{NO}_{3}\right]$ ) (see text for the significance of the symbols). ecular space. The amplitude of this $\mathrm{pH}$ pulse depends on the type and concentration of the protein molecules, as well as the value of $\mathrm{pH}_{\mathrm{b}}$. A typical response of an ISFET covered with a lysozyme membrane (polystyrene/agarose matrix) to a stimulus of $10 \mathrm{mM} \mathrm{KNO}$ to $50 \mathrm{mM} \mathrm{KNO}_{3}$ at $\mathrm{pH}_{\mathrm{b}}=4$ is shown in Fig. 3 .

At a $\mathrm{pH}_{\mathrm{b}}$ value of 4 the lysozyme is positively charged because $\mathrm{pH}_{\mathrm{iep}}=11$. This means that molecules react with a proton uptake, resulting in a temporary increase in the $\mathrm{pH}$ of the intramolecular space, monitored by the ISFET as a negative transient. The rise time of the transient is determined by the speed of the stimulus, while the fall time is determined by the lysozyme buffer capacity and the diffusion time for protons to redistribute.

It is clear from the considerations described above that for the measurement of the temporary change of the intramolecular $\mathrm{pH}$ in a protein membrane an ISFET is an excellent transducer because of its small and planar configuration and fast response time. On the other hand, the application of an ISFET has also a serious drawback: its intrinsic ability to respond to the ion concentration stimulus in a way similar to the protein molecules. The ISFET surface may also exhibit proton release or uptake upon a concentration step (van Kerkhof et al., 1994a). Due to convection the ISFET surface experiences the stimulus at about the same time as the protein molecules above the ISFET surface. However, the direct ISFET response is of a different shape and amplitude than the protein response.

ISFET vs. $\mathrm{Ag} / \mathrm{AgCl}$ at ion step $\mathrm{pH}=4$ Beads membrane with adsorbed lysozyme

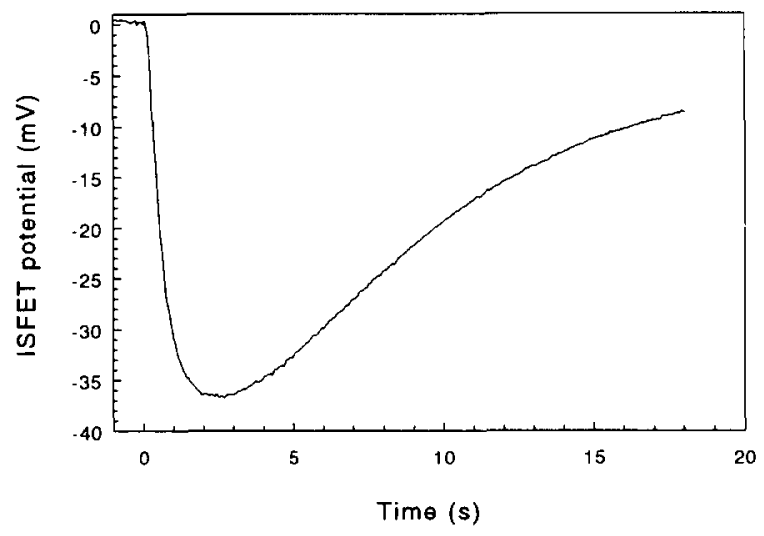

Fig. 3. Response of an ISFET covered with a lysozyme membrane using a stimulus of $10 \mathrm{mM}$ to $50 \mathrm{mM} \mathrm{KNO}_{3}$. 
Therefore various design rules for the system may help to prevent mixing of the two responses.

\section{PRACTICAL APPLICATION OF THE STIMULUS-RESPONSE METHOD WITH PROTEIN COVERED ISFETS}

By analyzing the origin of proton release or uptake from the ISFET surface and the protein molecules, we can conclude that the sign of the two responses depends on the value of $\mathrm{pH}_{\mathrm{b}}$ with respect to that of $\mathrm{pH}_{\mathrm{pzc}}$ and respectively $\mathrm{pH}_{\mathrm{iep}}$. When $\mathrm{pH}_{\mathrm{b}}=\mathrm{pH}_{\mathrm{pzc}}$ the ISFET does not respond and when $\mathrm{pH}_{\mathrm{b}}=\mathrm{pH}_{\mathrm{iep}}$ the protein molecules do not respond. This means that a practical value of $\mathrm{pH}_{\mathrm{b}}$ is $\mathrm{pH}_{\mathrm{pzc}}$ for the particular ISFET in order to be sure that the measured response only originates from the reaction of the protein molecules. The values of $\mathrm{pH}_{\mathrm{pzc}}$ for the usual gate oxides are: $\mathrm{SiO}_{2}$ : $\mathrm{pH} 2 \cdot 6-3 \cdot 2$ (Bousse et al., 1991); $\mathrm{Si}_{3} \mathrm{~N}_{4}$ : pH 2-5 (Bousse et al., 1992); $\mathrm{Al}_{2} \mathrm{O}_{3}: \mathrm{pH}$ 4.8-9.0 (Wong, 1985) and $\mathrm{Ta}_{2} \mathrm{O}_{5}: \mathrm{pH}$ 2.7-3 (Bousse et al., 1991). These fixed values of $\mathrm{pH}_{\mathrm{pzc}}$ limit the choice of the ISFET to be applied for a desired value of $\mathrm{pH}_{\mathrm{b}}$ as may be imposed by the type of protein molecules to be investigated. In this respect it is worthwhile investigating surface modification techniques for the usual ISFET gate oxides in order to design ISFETs with any desired value of $\mathrm{pH}_{\mathrm{pzc}}$ (van Kerkhof et al., 1994b).

The inverse of the solution suggested above is that for a value of $\mathrm{pH}_{\mathrm{b}}=\mathrm{pH}_{\text {iep }}$ the protein molecules will not respond to an ion concentration stimulus and thus, assuming an ISFET $\mathrm{pH}_{\mathrm{pzc}} \neq$ $\mathrm{pH}_{\mathrm{iep}}$, only the ISFET will respond. In a practical situation stimulus-response measurements around $\mathrm{pH}_{\mathrm{iep}}$ are therefore less reliable as already observed in the initial experiments by Schasfoort et al. (1990b).

Under practical conditions, which do not fulfil the ideal situation mentioned above $\left(\mathrm{pH}_{\mathrm{b}}=\right.$ $\mathrm{pH}_{\mathrm{pzc}}$ ), the direct ISFET response can also be masked. The eventual proton release from the ISFET surface will vanish quickly due to the large buffer capacity of the protein membrane, while using a relative thick protein membrane the proton release of the protein molecules will result in a rather prolonged $\Delta \mathrm{pH}$ in the membrane due to the large ratio between active surface and volume, and due to slow diffusion to the electrolyte bulk. In this way separation of the two effects in the time domain facilitates the measurement of the protein response. Furthermore, depending on the value of $\mathrm{pH}_{\mathrm{b}}$ with respect to $\mathrm{pH}_{\mathrm{pzc}}$, the ISFET may respond with a proton release (negative surface charge), while protein molecules with a positive surface charge at that value of $\mathrm{pH}_{\mathrm{b}}$ will respond with a proton uptake. In such a case the direct ISFET response will be quickly diminished. This is the reason why the lysozyme response as given in Fig. 3 does not show any direct ISFET response. In general it can be stated that the larger the difference between $\mathrm{pH}_{\mathrm{b}}$ and $\mathrm{pH}_{\mathrm{iep}}$, the more the protein molecules will dominate the overall response. However, in the case where a certain electrolyte interlayer exists between the ISFET surface and the protein membrane, the direct ISFET response will become distinguishable because the protein effect on the ISFET effect will be delayed. Examples are shown in Fig. $4 a$ and $b$.

The considerations given above lead to the design rule that, although the density of the protein molecules should not necessarily be as high as possible, the distance to the ISFET surface should be minimal anyway; this is not because of the protein molecules, but because of the limitation of the direct ISFET response. In this respect a membrane consisting of a matrix of polystyrene beads provided with receptor molecules is less favourable than a covalently bound monolayer of receptor molecules. This system can be considered as an ISFET with a modified surface (van Kerkhof et al., 1994c) and the response of this modified ISFET is the actual measurand.

In the case of a porous membrane matrix in which the adsorbed concentration of protein molecules is so high that the corresponding double layers overlap, the intramolecular space will no longer exhibit the $\mathrm{pH}$ value $\mathrm{pH}_{\mathrm{b}}$, but a value $\mathrm{pH}_{\mathrm{i}}$, which will lie somewhere between $\mathrm{pH}_{\mathrm{b}}$ and $\mathrm{pH}_{\mathrm{s}}$. Macroscopically, the membrane will show a certain potential, $\psi_{m}$, with respect to the bulk electrolyte. This is due to the Donnan effect, which not only develops the Donnan potential $\psi_{\mathrm{m}}$, but also causes a redistribution of all other ions. Nevertheless the effects of proton release or uptake are still present and can be described as given in this paper. However for a measurement one should distinguish between the application of an external reference electrode, or an internal, $\mathrm{Ag} / \mathrm{AgCl}$ electrode shaped around the ISFET gate. In the first case $\Delta \mathrm{pH}+\Delta \psi_{\mathrm{m}}$ 
a
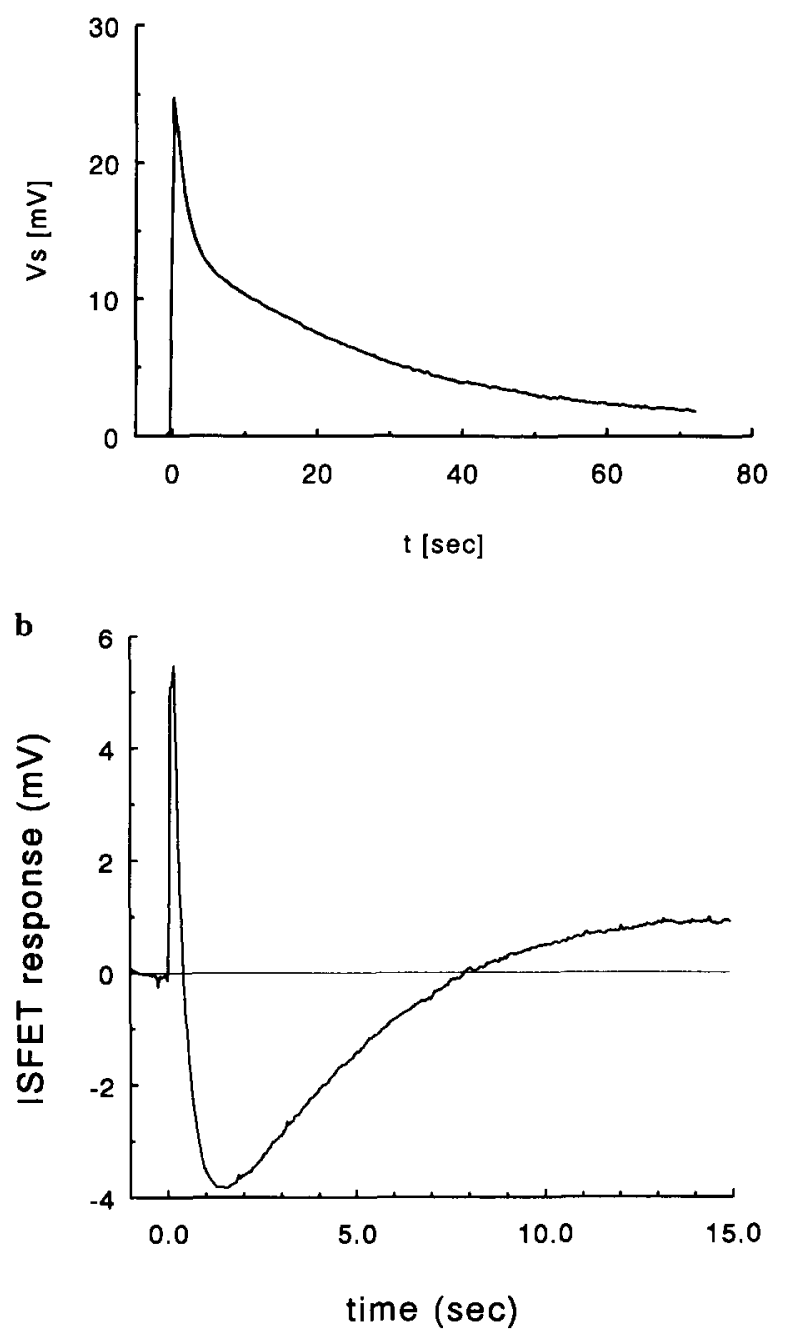

Fig. 4. a. Typical example of partly overlapping responses of an ISFET (sharp initial peak) and an approximately $10 \mu \mathrm{m}$ thick membrane of sulphonated polystyrene beads $(\varnothing=110 \mathrm{~nm})$ crosslinked with agarose, deposited onto the ISFET surface (slow response). Both "surfaces" are negatively charged at $p H=6$ and thus exhibit a positive transient upon an ion step of $10 \mathrm{mM}$ to $100 \mathrm{mM} \mathrm{KCl}$

b. Typical example of partly overlapping responses of an ISFET (positive peak) and an approximately $10 \mu \mathrm{m}$ thick membrane of amino-terminated polystyrene beads $(\varnothing=1 \mu \mathrm{m})$ crosslinked with agarose, containing covalently coupled protamine, deposited onto the ISFET surface (negative response). The negatively charged ISFET surface $(\mathrm{pH}=7)$ results as in Fig. $4 a$ in a positive transient, whilst the protamine layer is positively charged at $\mathrm{pH}=7$, thus resulting in a negative response to the ion step of 10 to $50 \mathrm{mM} \mathrm{KNO}$. will be measured, in the second case only $\Delta \mathrm{pH}$, according to the theory and model given in this paper. Such a measurement is more easily interpreted and it is therefore preferable to apply an internal reference electrode. This fact also makes the application of an ISFET, being a small planar electrode, favourable, because of the easy integration possibility with a $\mathrm{Ag} / \mathrm{AgCl}$ electrode.

\section{CONCLUSIONS}

A consideration of the operational mechanism of an ISFET in terms of the chemical surface buffer capacity and the electrical double layer capacitance led to a simple theoretical description of the ISFET sensitivity parameter $\alpha$, predicting a nearly Nernstian response for gate oxides with a large intrinsic buffer capacity of the surface. This theoretical approach is in fact built on the relatively old model and related theoretical description of the acid-base behaviour of protein molecules. In this respect the similarities between oxide and protein molecule surfaces are amazing.

Based on this insight a new measuring technique could be introduced, itself based on disturbance of an equilibrium of protein molecules deposited on the gate of an ISFET. An explanation has been provided as to how a concentration stimulus leads to a temporary $\mathrm{pH}$ change in the intramolecular space between the protein molecules, measurable by the ISFET. An optimal design rule for such a system could be developed, which may lead to a large variety of ISFET affinity based biosensors in the future.

\section{ACKNOWLEDGMENT}

The first stimulus response measurements were carried out by Richard Schasfoort, a former $\mathrm{Ph}$.D. student of the first author. The present theoretical insight into the measurements was developed by the third author Jan Eijkel as a Ph.D. student, whilst the second author Ronald van Hal has been very active in developing the corresponding theoretical description of the ISFET behaviour as a Ph.D. student. Application of the stimulus response method in many practical cases is greatly enhanced by the work of Ph.D. student Joost van Kerkhof. The present paper could therefore only be written due to the hard working of these students, financially supported 
by the Dutch foundation of Technical Sciences (STW), the Dutch Foundation for Research on Matters (FOM) and the TNO division TNOvoeding Zeist.

\section{REFERENCES}

Bergveld, P. (1972). Development, operation and application of the ion-sensitive field-effect transistor as a tool for electrophysiology. IEEE Transaction Biomedical Engineering, vol. BME-19, 342-351.

Bousse, L., de Rooy, N.F. \& Bergveld, P. (1983). Operation of chemically sensitive field-effect sensors as a function of the insulator-electrolyte interface. IEEE Trans. on Electron Dev., vol ED30, 1263-1270.

Bousse, L., Mostarshed, S., van der Schoot, B.H., de Rooij, N.F., Gimmel, P. \& Göpel, W. (1991). Zeta potential measurements of $\mathrm{Ta}_{2} \mathrm{O}_{5}$ and $\mathrm{SiO}_{2}$ thin films. J. Colloid Int. Sci., 147, 22-32.

Bousse, L.J., Mostarshed, S. \& Hafeman, D. (1992). Combined measurement of surface potential and zeta potential at insulator/electrolyte interfaces. Sensors \& Actuators, B-10, 67-71.

Debye, P. \& Hückel, E. (1923). The theory of electrolytes I. Lowering of freezing point and related phenomena. Physik. Z., 24, 185-206.

van Kerkhof, J.C., Eijkel, J.C.T. \& Bergveld, P. (1994a). ISFET responses on a stepwise change in electrolyte concentration at constant $\mathrm{pH}$, Sensors \& Actuators, B-18, no. 1-3, 56-59.

van Kerkhof, J.C., Bergveld, P. \& Schasfoort, R.B.M. (1994b). A heparin sensor based on a modified $\mathrm{TA}_{2} \mathrm{O}_{5}$-ISFET and the ion-step measuring method. In: Proc. of the Dutch Conference on Sensor Technology 1994. P.V. Lambeck (ed.), Univ. of Twente, Enschede, The Netherlands, pp. 281-285, ISBN 90-73461-06-5. van Kerkhof, J.C., Bergveld, P. \& Schasfoort, R.B.M $(1994 c)$. The ISFET based heparine sensor with a monolayer of protamine as affinity ligand. Biosensors \& Bioelectronics. (accepted).

Kuriyama, T, Kimura, J. \& Kawana. Y. (1985). Development of biosensors with immobilized enzyme. Chemical Economy \& Engineering Rev., 17, 22-27.

Linderstrøm-Lang, K. (1924). The ionization of proteins. Compt. Rend. Trav. Lab. Carlsberg, Sér. Chim., 15, nr. 7.

Schasfoort, R.B.M., Bergveld, P., Kooyman, R.P.M. \& Greve, J. (1990a). Possibilities and limitations of direct detection of protein charges by means of an immunological field-effect transistor. Analytical Chimica Acta, 238, 323-329.

Schasfoort, R.B.M., Kooyman, R.P.M., Bergueld, P. \& Greve, J. (1990b). A new approach to ImmunoFET operation. Biosensors \& Bioelectronics, 5, 103-124.

Schenck, J.F. (1978). Technical difficulties remaining to the application of ISFET devices. In: Theory, Design and Biomedical Applications of Solid State Chemical Sensors, P.W. Cheung (ed.), CRC Press Inc., pp. 165-173.

van der Schoot, B.H. \& Bergveld, P. (1988). ISFETbased enzyme sensors. Biosensors, 2, 161-186.

van der Schoot, B.H. \& Bergveld, P. (1990). Evaluation of the sensor properties of the $\mathrm{pH}$-static enzyme sensor. Analytical Chimica Acta, 233, 49-57.

US Patent 4,020,830, (1977). Selective chemical sensitive FET transducers. University of Utah, Salt Lake City.

Westall, J. \& Hohl. H. (1980). A comparison of electrostatic models for the oxide/solution interface. Adv. Colloid Interface Science, 12, 265-294.

Wong, A.S. (1985). Theoretical and experimental studies of CVD aluminium oxide as a $\mathrm{pH}$-sensitive dielectric for the back contacts ISFET sensor. $\mathrm{PhD}$ Thesis, Case Western Reserve University. 